\title{
Kemampuan Menulis Puisi Siswa Kelas X SMA Negeri 7 Kota Bengkulu
}

\author{
Afifah $^{* 1}$, Didi Yulistio ${ }^{2}$, Rio Kurniawan ${ }^{3}$ \\ Program Studi (S-1) Pendidikan Bahasa Indonesia, Universitas Bengkulu ${ }^{1,2,3}$ \\ Corresponding email: afifahgutlak@gmail.com
}

\begin{abstract}
Research objectives know the poetry writing skills of first-grade students of SMA Negeri 7 Bengkulu city. This research uses descriptive methods with quantitative approaches. The population in this study was all first-grade students of SMA Negeri 7 Bengkulu city with 425 students in total. Samples in this study used simple random sampling as much as $15 \%$ of 63 population. Data collection technique is a documentation technique with test result of writing student poems that have become documents archived by the teacher. The ability to write poetry is judged on five aspects, namely the accuracy of the content with the title, the choice of words, the use of majas and symbolism, the utilization of verification (rhyme and rhythm), and typography. The data analysis technique used is a simple statistic by calculating the average value. The results of this study showed that the average ability in write poetry first-grade students SMA Negeri 7 Bengkulu city is 58.30 with enough category. The average ability to write student poems based on the accuracy aspect of the content and title is 16.33 with good categories, the average ability to write student poems based on the aspect of word choice is 14.20 with enough categories, the average ability to write student poems based on aspects of majas use and symbolism is 10.63 with enough categories, the average ability to write student poetry based on aspects of verification utilization (rhyme and rhythm) is 9.40 with enough category, the average ability to write student poetry based on typographic aspects is 7.87 with enough categories.
\end{abstract}

Keywords: ability, writing poetry, students

\begin{abstract}
Abstrak
Tujuan penelitian ini mengetahui kemampuan menulis puisi siswa kelas X SMA Negeri 7 Kota Bengkulu. Penelitian ini menggunakan metode deskriptif dengan pendekatan kuantitatif. Populasi dalam penelitian ini semua siswa kelas X SMA Negeri 7 Kota Bengkulu yang berjumlah 425 orang siswa. Sedangkan sampel dalam penelitian ini menggunakan simple random sampling yaitu sampel acak sebanyak $15 \%$ dari jumlah populasi yaitu 63 orang siswa.Teknik pengumpulan data menggunakan teknik dokumentasi berupa hasil tes menulis puisi siswa yang sudah menjadi dokumen yang diarsipkan guru. Kemampuan menulis puisi ini dinilai dari lima aspek, yaitu ketepatan isi dengan judul, pilihan kata atau diksi, penggunaan majas dan perlambangan, pemanfaatan verifikasi (rima dan ritma), serta tipografi. Teknik analisis data yang digunakan dalam penelitian ini yaitu, statistik sederhana dengan menghitung nilai rata-rata. Hasil penelitian ini
\end{abstract}


menunjukkan bahwa rata-rata kemampuan menulis puisi kelas X SMA Negeri 7 Kota Bengkulu adalah 58,30 dengan kategori cukup. Rata-rata kemampuan menulis puisi siswa berdasarkan aspek ketepatan isi dengan judul adalah 16,33 dengan kategori baik, rata-rata kemampuan menulis puisi siswa berdasarkan aspek pilihan kata atau diksi adalah 14,20 dengan kategori cukup, rata-rata kemampuan menulis puisi siswa berdasarkan aspek penggunaan majas dan perlambangan adalah 10,63 dengan kategori cukup, rata-rata kemampuan menulis puisi siswa berdasarkan aspek pemanfaatan verifikasi (rima dan ritma) adalah 9,40 dengan kategori cukup, rata-rata kemampuan menulis puisi siswa berdasarkan aspek tipografi adalah 7,87 dengan kategori cukup.

Kata kunci: kemampuan, menulis puisi, siswa

\section{PENDAHULUAN}

Keterampilan menulis merupakan keterampilan berbahasa yang paling kompleks, sebab keterampilan menulis dilakukan setelah tiga aspek kebahasaan yang sebelumnya yaitu keterampilan menyimak, keterampilan berbicara, dan keterampilan membaca (Puspita, 2016). Keempat keterampilan berbahasa tersebut pada dasarnya merupakan satu kesatuan yang saling melengkapi antara satu dengan yang lainnya.

Keterampilan menulis merupakan keterampilan yang perlu dilatih secara intensif dibandingkan dengan keterampilan-keterampilan yang lainnya karena siswa menganggap menulis merupakan hal yang sulit untuk dilakukan (Noermanzah dkk., 2018). Keterampilan menulis sangat penting bagi setiap siswa karena menulis merupakan sebuah metode terbaik untuk mengembangkan suatu kemampuan dalam menggunakan bahasa (Kusumaningsih dkk., 2013). Menulis merupakan suatu keterampilan berbahasa yang digunakan untuk berkomunikasi secara tidak langsung dan tidak tatap muka. Menulis juga merupakan suatu kegiatan yang produktif dan ekspresif (Tarigan, 2013).

Pada prinsipnya menulis bertujuan untuk menyampaikan pesan penulis kepada pembaca, sehingga pembaca dapat memahami maksud yang disampaikannya melalui tulisan tersebut (Kusumaningsih dkk., 2013). Untuk meningkatkan kemampuan menulis, tidak dapat dilakukan dengan pembelajaran teori saja, akan tetapi harus melalui latihan-latihan yang tersusun sehingga mendapatkan hasil yang maksimal atau baik. Dalam melakukan kegiatan menulis, penulis harus menguasai struktur bahasa dan terampil dalam menggunakan kosakata.

Berdasarkan Kurikulum 2013 (K13) siswa dituntut untuk dapat terampil dalam kegiatan menulis. Salah satu keterampilan menulis yang harus dikuasai siswa adalah menulis suatu karya sastra berupa puisi. Menurut Sutardi (2012) dan Satinem dkk. (2020) puisi merupakan ungkapan perasaan atau ekspresi perasaan penyair yang dituliskan dengan bahasa yang indah dan bermakna yang terikat yang terikat irama, rima, matra, penyusunan lirik, dan bait. Wardoyo (2013) juga menjelaskan puisi merupakan pengalaman, imajinasi, dan sesuatu berkesan yang dituliskan sebagai ekspresi seseorang dengan menggunakan bahasa yang tidak langsung, indah, dan bermakna.

Untuk mengukur tingkat kemampuan menulis puisi siswa bisa diukur dengan menggunakan beberapa aspek yaitu ketepatan isi dengan judul, pilihan kata atau diksi, penggunaan majas dan perlambangan, pemanfaatan verifikasi (rima dan ritma), dan tipografi (Rusmiyanti, 2018; Sehah, 2016). Menurut Haliq dkk. (2017), 
penggunaan diksi yang tepat dalam judul juga harus diperhatikan, karena judul yang baik dan kreatif akan memancing pembaca untuk membaca keseluruhan isi puisi, isi puisi harus sesuai dengan pemilihan judul yang lebih dahulu ditetapkan.

Menurut Suyitno (2009) dan Zahro dkk. (2020) pemilihan kata dan pemanfaatan kata merupakan aspek yang utama dalam menentukan indah dan bermaknanya sebuah puisi. Artinya diksi merupakan hal yang sangat penting atau dasar dalam penulisan puisi. Menurut Suyitno (2009) diksi atau kata-kata yang dipilih dalam menulis puisi yang baik adalah kata-kata yang berjiwa, kata berjiwa yang dimaksudkan perasaan penyair yang sudah dimasukkan suasana hati dan pikiran penyair.

Menurut Perrine dalam Waluyo (2008) dan Noermanzah (2012) mengatakan bahwa bahasa figuratif dipandang lebih efektif untuk menyatakan apa yang dimaksud penyair, karena: (1) bahasa figuratif mampu menghasilkan kesenangan imajinatif; (2) bahasa figurtif menghasilkan imajinasi tambahan dalam puisi; (3) bahasa figuratif mampu menambahkan intensitas perasaan penyair untuk puisinya dan menyampaikan sikap penyair; (4) bahasa figuratif yaitu cara untuk mengkonsentrasikan makna yang hendak disampaikan dan cara menyampaikan sesuatu yang banyak dan luas dengan bahasa singkat.

Menurut Waluyo (2008) rima merupakan pengulangan bunyi dalam puisi untuk membentuk musikalitas atau orkestra yang dengan pengulangan bunyi tersebut, puisi menjadi merdu jika dibaca dan untuk pengulangan bunyi tersebut, pemilihan bunyi-bunyi ini mendukung perasaan dalam suasana puisi (Makatita \& Sasabone, 2019). Artinya, puisi yang baik salah satunya dipengaruhi oleh rima atau pengulangan bunyi yang merdu jika dibaca dan menggunakan pemilihan bunyi-bunyi yang dapat mendukung perasaan dalam suasana puisi.

Tipografi merupakan aspek bentuk visual puisi yang berupa tata hubungan dan tata baris (Hasanah, 2014). Oleh karena itu tipografi juga disebut sebagai bentuk penulisan puisi yang menyangkut pembaitan-enjebemen, penggunaan huruf, tanda baca, dan bentuk bait, serta susunan baris (Sutardi, 2012). Selain berfungsi sebagai sarana untuk mendapatkan bentuk yang menarik, tipografi juga berfungsi sebagai pembeda yang sangat penting antara puisi dengan prosa, serta sarana untuk menyampaikan pesan secara tidak langsung kepada pembaca (Jabrohim dkk., 2003).

Pembelajaran menulis puisi di sekolah merupakan salah satu langkah untuk memperkenalkan siswa dengan puisi. Dengan menulis puisi diharapkan siswa mampu mengungkapkan gagasan, pikiran, dan perasaan ke dalam bentuk tulisan yang indah dan bermakna. Pembelajaran menulis puisi di sekolah bertujuan agar siswa dapat memperoleh kesadaran yang lebih baik terhadap dirinya sendiri, orang lain, maupun di lingkungan sekitar dan memperoleh kesenangan, pengetahuan dasar tentang puisi serta untuk menanamkan rasa peka terhadap suatu karya sastra sehingga dapat memunculkan rasa senang dan tertarik terhadap apresiasi sastra (Emzir, 2015). Selain itu, pembelajaran menulis puisi penting dan sangat bermanfaat bagi siswa karena dapat menstimulus otak sehingga siswa mampu berpikir lebih kreatif dan simpatik terhadap lingkungan dan sekitar.

Pada kenyataannya pembelajaran menulis puisi merupakan kegiatan pembelajaran yang masih sukar untuk dilakukan pada jenjang SMA, khususnya pada SMA Negeri 7 Kota Bengkulu. Hal tersebut didapatkan berdasarkan observasi awal yang dilakukan di SMA Negeri 7 Kota Bengkulu, peneliti melakukan wawancara kepada guru kelas $X$ dan guru penanggung jawab ekstrakurikuler bidang sastra. Dari 
hasil wawancara, guru mengatakan bahwa siswa mengalami kesulitan dalam memahami unsur-unsur pembentukan puisi dan memaknai sebuah puisi secara keseluruhan. Siswa juga merasa bosan dengan pembelajaran puisi karena kurangnya minat terhadap pembelajaran ini. Dalam menulis puisi, sebagian siswa biasanya bingung memilih kata-kata yang tepat dalam membentuk keterpaduan makna, bentuk dan bunyi yang indah dalam puisi. Hal ini terjadi karena siswa kurang berminat, semangat, dan kurang termotivasi dalam menulis puisi sehingga berdampak kepada aktivitas siswa yang masih kurang. Padahal, berdasarkan wawancara tersebut, guru sudah melakukan metode pembelajaran menyenangkan seperti pergi keluar kelas untuk memancing siswa dalam menulis puisi, melihat-lihat benda-benda yang ada di dalam kelas dalam dijadikan inspirasi untuk menulis puisi. Hal ini berlawanan dengan pendapat Sutardi (2012) bahwa hal yang dibutuhkan dalam kreativitas menulis bukanlah teknik yang instan, melainkan lebih kepada semangat dan ikrar yang kuat, yang dimulai dari diri sendiri. Semangat merupakan modal utama untuk memulai menulis.

Rumusan masalah dalam penelitian ini adalah "Bagaimana kemampuan menulis puisi siswa kelas X SMA Negeri 7 Kota Bengkulu?" dan "Bagaimana kemampuan menulis puisi siswa kelas X SMA Negeri 7 Kota Bengkulu yang dilihat dari aspek ketepatan isi dengan judul, pilihan kata atau diksi, penggunaan majas dan perlambangan, pemanfaatan verifikasi (rima dan ritma), penggunaan tipografi? Penelitian ini bertujuan untuk mendeskripsikan kemampuan menulis puisi siswa kelas X SMA Negeri 7 Kota Bengkulu, serta untuk mendeskripsikan kemampuan menulis puisi siswa kelas X SMA Negeri 7 Kota Bengkulu yang dilihat dari aspek ketepatan isi dengan judul, kemampuan menulis puisi siswa kelas X SMA Negeri 7 Kota Bengkulu yang dilihat dari aspek pilihan kata atau diksi, kemampuan menulis puisi siswa kelas $X$ SMA Negeri 7 Kota Bengkulu yang dilihat dari aspek penggunaan majas dan perlambangan, kemampuan menulis puisi siswa kelas X SMA Negeri 7 Kota Bengkulu yang dilihat dari aspek pemanfaatan verifikasi (rima dan ritma), kemampuan menulis puisi siswa kelas X SMA Negeri 7 Kota Bengkulu yang dilihat dari aspek penggunaan tipografi. Penelitian ini memberikan manfaat yang dapat menjadi bahan pertimbangan dan masukan terhadap pengajaran bahasa Indonesia khususnya pada pembelajaran menulis puisi di SMA Negeri 7 Kota Bengkulu. Selain itu, juga sebagai bahan pertimbangan dalam penerapan dan penyampaian metode pembelajaran yang akan digunakan.

Berdasarkan penjabaran di atas, peneliti melakukan penelitian dengan judul "Kemampuan Menulis Puisi Siswa Kelas X SMA Negeri 7 Kota Bengkulu". Alasan lain tertarik melakukan penelitian dengan judul ini adalah dengan beberapa pertimbangan bahwa peneliti melakukan kegiatan magang II di SMA Negeri 7 Kota Bengkulu sehingga sedikit banyaknya sudah paham dengan kondisi sekolah tersebut. Selain itu, penelitian terkait hal ini belum pernah dilakukan di SMA Negeri 7 Kota Bengkulu.

\section{METODE}

Penelitian ini menggunakan pendekatan kuantitatif dengan metode deskriptif yaitu apa adanya sesuai dengan fakta yang ada mengenai kemampuan menulis puisi dari peserta didik. Penelitian ini dilakukan di SMA Negeri 7 Kota Bengkulu yang terletak di jalan Sadang, Lingkar Barat, Gading Cempaka Kota Bengkulu. Waktu penelitian ini dilakukan pada semester genap tahun ajaran 2019/2020. 
Adapun teknik pengambilan sampel pada penelitian ini menggunakan teknik simple random sampling. Peneliti mengambil sampel secara homogen yaitu sebanyak $15 \%$ dari populasi yang ada. Maka didapatkan 15\% dari 425 adalah 63 orang. Jadi, sampel yang digunakan dalam penelitian ini adalah sebanyak 63 sampel.

Teknik pengumpulan data dalam penelitian ini menggunakan teknik dengan sumber sekunder, artinya pengumpulan data pada penelitian ini didapat dari dokumentasi berupa hasil tes menulis puisi siswa kelas X SMA Negeri 7 Kota Bengkulu yang sudah menjadi dokumen yang diarsip guru. Bentuk tes yang digunakan dalam penelitian ini adalah tes verbal tertulis, sehingga wujud data dalam penelitian ini berupa skor hasil belajar yang menggambarkan kemampuan siswa dalam menulis puisi.

Instrumen penelitian ini menggunakan analisis tes untuk mengetahui kemampuan menulis puisi siswa pada kelas X SMA Negeri 7 Kota Bengkulu. Kemudian, teknik analisis data yang diginakan dalam penelitian ini adalah dengan teknik statistik deskriptif. Setelah data penelitian terkumpul maka, untuk mengetahui gambaran tersebut diambil langkah-langkah sebagai berikut:

a) Memberikan penilaian atau skor puisi siswa. Penelitian dilakukan oleh dua orang penilai yaitu peneliti sendiri sebagai penilai satu (P1) dan penilai dua (P2) guru bahasa Indonesia kelas X SMA Negeri 7 Kota Bengkulu.

b) Menggabungkan skor dari kedua penilai yaitu $P(1)$ dan $P(2)$.

c) Menghitung nilai rata-rata siswa.

d) Menentukan kemampuan menulis siswa dengan menggunakan kriteria atau klasifikasi sesuai dengan table dibawah ini:

Tabel 1. Kriteria atau Klasifikasi Kemampuan Menulis Puisi

\begin{tabular}{ccc}
\hline No. & $\begin{array}{c}\text { Presentasi Tingkat } \\
\text { Penguasaan }\end{array}$ & Keterangan \\
\hline 1. & $85-100$ & Sangat Baik \\
\hline 2. & $70-84$ & Baik \\
\hline 3. & $56-69$ & Cukup \\
\hline 4. & $45-55$ & Kurang \\
\hline 5. & $1-44$ & Sangat Kurang \\
\hline & & Sumber: Nurgiyantoro (2010)
\end{tabular}

\section{HASIL}

Hasil penelitian ini merupakan data kemampuan menulis puisi pada siswa kelas X SMA Negeri 7 Kota Bengkulu dengan jumlah 63 siswa sebagai sampel. Untuk melihat kemampuan menulis puisi siswa diuji dengan lima aspek yaitu: ketepatan isi dengan judul, pilihan kata atau diksi, penggunaan majas dan perlambangan, pemanfaatan verifikasi (rima dan irama), serta penggunaan tipografi.

Hasil perhitungan kemampuan menulis puisi siswa kelas X SMA Negeri 7 Kota Bengkulu yang dianalisis dari hasil rata-rata pada setiap aspek yang diperoleh oleh siswa dapat dilihat dari tabel berikut. 
Tabel 2. Kemampuan Menulis Puisi Siswa Kelas X SMA Negeri 7 Kota Bengkulu

\begin{tabular}{clcc}
\hline No. & \multicolumn{1}{c}{ Aspek yang Dilihat } & $\begin{array}{c}\text { Rata-rata } \\
\text { Nilai }\end{array}$ & Kategori \\
\hline 1. & Ketepatan Isi dengan Judul & 16,33 & Baik \\
\hline 2. & Pilihan Kata atau Diksi & 14,20 & Cukup \\
\hline 3. & $\begin{array}{l}\text { Penggunaan Majas } \\
\text { Perlambangan }\end{array}$ & 10,63 & Cukup \\
\hline 4. & $\begin{array}{l}\text { Pemanfaatan Verifikasi (rima dan } \\
\text { ritma) }\end{array}$ & 9,40 & Cukup \\
\hline 5. & Penggunaan Tipografi & 7,87 & Cukup \\
\hline & Rata-rata & 58,30 & Cukup \\
\hline
\end{tabular}

Dari tabel di atas dapat diperoleh nilai rata-rata kemampuan menulis puisi siswa kelas X SMA Negeri 7 Kota Bengkulu adalah 58,30. Nilai tersebut apabila dilihat dari kriteria penilaian termasuk dalam kategori cukup, karena terletak pada interval 56-69. Artinya menunjukkan bahwa siswa belum baik dalam menulis puisi dari beberapa aspek, pembaca masih belum sepenuhnya memahami tulisan atau puisi yang ditulis siswa, puisi yang ditulis siswa masih banyak menggunakan pilihan kata yang biasa saja atau kata yang biasa digunakan secara umum, serta puisi yang ditulis siswa sebagian besar belum menunjukkan bunyi yang merdu.

Hasil perhitungan kemampuan menulis puisi siswa kelas X SMA Negeri 7 Kota Bengkulu jika dimasukkan dalam interval skala lima untuk perhitungan skor adalah sebagai berikut.

Tabel 3. Tingkat Penguasaan Kemampuan Menulis Puisi Siswa

\begin{tabular}{cccc}
\hline No & $\begin{array}{c}\text { Presentasi Tingkat } \\
\text { Penguasaan }\end{array}$ & $\begin{array}{c}\text { Frekuensi } \\
\text { siswa }\end{array}$ & Keterangan \\
\hline 1. & $85-100$ & 7 & Sangat Baik \\
\hline 2. & $70-84$ & 6 & Baik \\
\hline 3. & $56-69$ & 26 & Cukup \\
\hline 4. & $45-55$ & 16 & Kurang \\
\hline 5. & $1-44$ & 8 & Sangat Kurang \\
\hline
\end{tabular}

Berdasarkan tabel di atas, maka grafik yang terbentuk dari hasil kemampuan menulis puisi siswa adalah sebagai berikut:

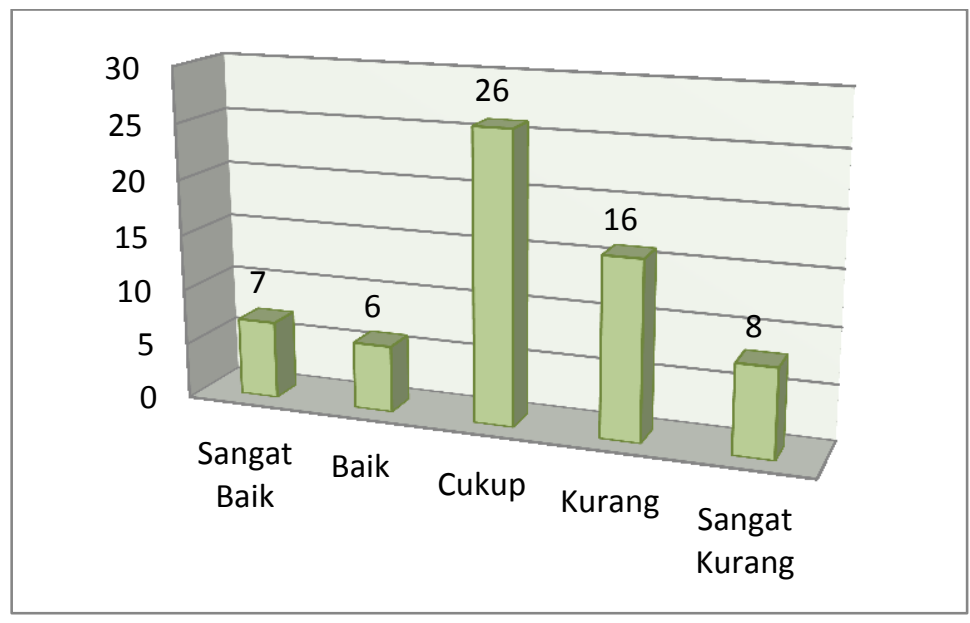

Diagram 1. Kemampuan Menulis Puisi Siswa Kelas $X$ SMA Negeri 7 Kota Bengkulu 
Berdasarkan hasil perhitungan frekuensi pada grafik tersebut, dapat diketahui bahwa kemampuan menulis puisi siswa kelas X SMA Negeri 7 Kota Bengkulu terbagi menjadi 7 siswa temasuk pada kategori nilai sangat baik, 6 siswa termasuk kategori baik, 26 siswa termasuk kategori cukup, 16 siswa termasuk kategori kurang, dan 8 siswa termasuk kategori sangat kurang.

\section{PEMBAHASAN}

Berdasarkan analisis data, maka kemampuan menulis puisi pada siswa kelas $X$ SMA Negeri 7 Kota Bengkulu termasuk dalam kategori cukup. Kategori cukup artinya menunjukkan bahwa siswa belum baik dalam menulis puisi dari beberapa aspek, pembaca masih belum sepenuhnya memahami tulisan atau puisi yang ditulis siswa, puisi yang ditulis siswa masih banyak menggunakan pilihan kata yang biasa saja atau kata yang biasa digunakan secara umum, serta puisi yang ditulis siswa sebagian besar belum menunjukkan bunyi yang merdu. Hal tersebut kurang relevan dengan pendapat Suwarna (2012) bahwa syarat indahnya puisi harus dipenuhi dengan pertimbangan kata-kata yang baik dan bermakna. Dengan demikian, katakata yang dipilih bukanlah kata-kata biasa atau umum melainkan yang tidak biasa. Suwarna (2012) berpendapat bahwa puisi yang baik adalah puisi yang ditulis dengan nada yang tepat dan beraturan serta bunyi yang merdu. Hasil kemampuan menulis puisi siswa tersebut tidak menjadi hambatan bagi guru untuk lebih meningkatkan pembelajaran menulis puisi untuk kedepannya. Dengan adanya data nilai kemampuan tersebut dapat membantu guru dalam mengevaluasi hasil belajar menulis puisi siswa yang dapat menumbuhkan kesadaran bagi guru untuk terus semangat dalam mengasah kemampuan siswa dalam menulis puisi atau dalam mengapresiasi puisi.

Kemampuan menulis puisi pada siswa kelas X SMA Negeri 7 Kota Bengkulu dilihat dari aspek ketepatan isi dengan judul diperoleh rata-rata nilai sebesar 16.33. Nilai tersebut apabila dilihat dari aspek ketepatan isi dengan judul termasuk pada kategori baik karena teretak pada interval 6-20. Hal tersebut menunjukkan bahwa siswa sudah baik dalam menulis puisi dari aspek ketepatan isi dengan judul.

Hasil kemampuan menulis puisi pada aspek ketepatan isi dengan judul termasuk pada kategori baik karena judul puisi yang ditulis siswa sebagian besar sesuai dengan isi puisi dan judul yang ditulis juga kreatif dengan pemilihan diksi yang tepat. Hal tersebut relevan dengan pendapat Haliq (2018) dalam hasil penelitian yang pernah dilakukannya bahwa penggunaan diksi yang tepat dalam judul juga harus diperhatikan, karena judul yang baik dan kreatif akan memancing pembaca untuk membaca keseluruhan isi puisi, dan isi puisi harus sesuai dengan pemilihan judul yang lebih dahulu ditetapkan.

Kemampuan menulis puisi pada siswa kelas X SMA Negeri 7 Kota Bengkulu dilihat dari aspek pilihan kata atau diksi diperoleh rata-rata nilai sebesar 14.20. Nilai tersebut apabila dilihat dari aspek pilihan kata atau diksi termasuk pada kategori cukup karena teretak pada interval 11-15. Hal tersebut menunjukkan bahwa siswa belum baik dalam menulis puisi dari aspek pilihan kata atau diksi.

Hasil kemampuan menulis puisi pada aspek pilihan kata atau diksi termasuk pada kategori cukup karena puisi yang ditulis menggunakan kata-kata puitis tetapi belum begitu bagus dan pemilihan kata-kata pada puisi belum sepenuhnya menibulkan imajinasi estetis, belum sepenuhnya menghasilkan komposisi rima dan ritma, serta belum sepenuhnya dapat memperjelas makna dengan baik. Padahal pilihan kata atau diksi merupakan hal sangat penting dalam menulis sebuah puisi. 
Hal tersebut kurang relevan dengan pendapat Waluyo (2008) bahwa penulisan puisi yang baik, hendaknya: (a) didasari dengan kata-kata yang bersifat konotatif, artinya memiliki kemungkinan makna yang lebih dari satu, (b) menggunakan kata-kata yang puitis, artinya memiliki efek keindahan dan berbeda dengan kata-kata yang dipakai dalam kehidupan sehari-hari, (c) mempertimbangkan maknanya, komposisi bunyi dalam rima dan iraman, kedudukan kata itu dibawah konteks kata lainnya, dan keduduan kata dalam keseluruhan puisi. Hal ini juga diperkuat oleh Sutardi (2012) bahwa menulis puisi yang baik, hendaknya: (a) diksi atau pilihan kata yang dipilih harus padat dan selalu menimbulkan makna yang lebih, (b) diksi yang digunakan dapat menggambarkanatau menimbulkan pengalaman, perasaan imajinasian, dan keindahan. Dapat dikatakan bahwa kata merupakan persoalan pokok puisi atau kata merupakan bahan baku puisi.

Kemampuan menulis puisi pada siswa kelas X SMA Negeri 7 Kota Bengkulu dilihat dari aspek penggunaan majas dan perlambangan diperoleh rata-rata nilai sebesar 10.63. Nilai tersebut apabila dilihat dari aspek pilihan kata atau diksi termasuk pada kategori cukup karena teretak pada interval 9-12. Hal tersebut menunjukkan bahwa siswa belum baik dalam menulis puisi dari aspek penggunaan majas dan perlambangan.

Hasil kemampuan menulis puisi pada aspek penggunaan majas dan perlambangan termasuk pada kategori cukup karena puisi yang ditulis menggunakan gaya bahasa yang mampu membuat puisi menjadi lebih menarik dan hidup, kurang mampu menimbulkan kesegaran dan kedekatan dengan pembaca, serta kurang mampu memberikan kejelasan angan tentang isi puisi. Padahal penggunaan majas dalam puisi sangat dibutuhkan penyair untuk membangkitkan imajinasi pada puisi, serta dapat menarik perhatian pembaca. Hal tersebut kurang relevan dengan pendapat Perrine dalam Waluyo (2008) mengatakan bahwa menulis puisi yang baik di pandang daris segi majas hendaklah: (a) menggunakan majas yang mampu menghasilkan kesenangan imajimatif, (b) menggunakan majas yang mampu menghasilkan imajinasi tambahan dan kejelasan angan dalam puisi, (c) menggunakan majas yang dapat menambah intensitas perasaan penyair dan menyampaikan sikap penyair. (f) menggunakan majas untuk mengkonsentrasika makna yang hendak di sampaikan dengan singkat. (g) menggunakan gaya bahasa yang dapat membuat puisi menjadi lebih menarik. Dengan adanya bahasa figuratif, sajak akan dapat lebih menarik perhatian, menimbulkan kesegaran, dan terutama menimbulkan kejelasan gambaran angan penulis (Pradopo, 2014).

Kemampuan menulis puisi pada siswa kelas X SMA Negeri 7 Kota Bengkulu dilihat dari aspek pemanfaatan verifikasi (rima dan ritma) diperoleh rata-rata nilai sebesar 9.40. Nilai tersebut apabila dilihat dari aspek pilihan kata atau diksi termasuk pada kategori cukup karena terletak pada interval 7-9. Hal tersebut menunjukkan bahwa siswa belum baik dalam menulis puisi dari aspek pemanfaatan verifikasi (rima dan ritma).

Hasil kemampuan menulis puisi pada aspek verifikasi (rima dan ritma) termasuk pada kategori cukup karena penggunaan verifikasi (rima dan ritma) pada puisi pada sebagian besar mampu dalam menggunaan Verifikasi (rima, irama) yang dapat menumbuhkan kemerduan pada puisi, mampu dalam menggunaan Verifikasi (rima, irama) yang dapat menumbuhkan kesan suasana pada puisi, serta mampu dalam menggunaan Verifikasi (rima, irama) yang dapat mempertegas makna tertentu pada puisi. Hal tersebut kurang relevan dengan pendapat Waluyo (2008) mengatakan bahwa puisi yang baik dilihat dari segi pemanfaatan verifikasi salah 
satunya dipengaruhi oleh rima atau pengulangan bunyi yang merdu jika dibaca dan menggunakan pemilihan bunyi-bunyi yang dapat mendukung perasaan dalam suasana puisi.

Kemampuan menulis puisi pada siswa kelas X SMA Negeri 7 Kota Bengkulu dilihat dari aspek tipografi diperoleh rata-rata nilai sebesar7.84. Nilai tersebut apabila dilihat dari aspek pilihan kata atau diksi termasuk pada kategori cukup karena terletak pada interval 7-9. Hal tersebut menunjukkan bahwa siswa belum baik dalam menulis puisi dari aspek penggunaan tipografi.

Hasil kemampuan menulis puisi aspek tipografi termasuk pada kategori cukup. Karena puisi yang duitulis menggunakan tipografi yang mampu menampilkan aspek artistik visual puisi, kurang mampu menciptakan nuansa makna pada puisi, serta mampu menciptakan suasana tertentu pada puisi. Padahal penggunaan tipografi memiliki fungsi sebagai sarana penyampaian pesan kepada pembaca secara tidak langsung. Hal tersebut kurang relevan dengan pendapat Sutardi (2012), tipografi sangat penting sebagai media untuk mengungkapkan makna dalam puisi. Penggunaan tipografi yang baik pada puisi dapat meliputi beberapa hal antara lain: (a) aspek pembaitan-enjambemen berkaitan dengan penyusunan pembaitan karena pemutusan-pemutusan ungkapan yang diakukan. Dalam menulis puisi harus mempertimbangan ide gagasan yang ingin disampaikan sehingga koherensi makna pada puisi dapat terbentuk; (b) menggunakan huruf dan tanda baca, penggunaan huruf kecil-besar atau bentuk dan jenis huruf serta tanda baca yang dilakukan haruslah dalam rangka untuk membentuk koherensial makna, dan (c) bentuk pembaitan, bentuk pembaitan dalam puisi dalam kerangka untuk koherensi makna puisi dan menampilkan aspek artistik visual puisi.

\section{KESIMPULAN DAN SARAN}

Berdasarkan hasil penelitian dan pembahasan dapat disimpulkan bahwa kemampuan menulis puisi siswa pada kelas X SMA Negeri 7 Kota Bengkulu mendapatkan kategori cukup. Hal ini menunjukkan bahwa proses pembelajaran menulis puisi siswa secara keseluruhan belum baik dan maksimal.

Secara khusus hasil penelitian kemampuan menulis puisi pada siswa kelas $X$ SMA Negeri 7 Kota Bengkulu berdasarkan masing-masing aspek dapat disimpulkan sebagai berikut.

1. Pada aspek ketepatan isi dengan judul menulis puisi pada siswa kelas $X$ SMA Ngeri 7 Kota Bengkulu berada pada kategori baik. Hal ini menunjukkan bahwa siswa sudah baik dalam kegiatan menulis puisi yang dilihat dari aspek ketepatan isi dengan judul.

2. Pada aspek pilihan kata atau diksi menulis puisi siswa kelas X SMA Negeri 7 Kota Bengkulu berada pada kategori cukup. Hal ini menunjukkan bahwa siswa belum baik dalam menulis puisi dari aspek pilihan kata atau diksi.

3. Pada aspek penggunaan majas dan perlambangan berada pada kategori cukup. Hal ini menunjukkan bahwa siswa belum baik dalam menulis puisi yang dilihat dari aspek penggunaan majas dan perlambangan.

4. Pada aspek verifikasi (rima dan ritma) berada pada kategori cukup. Hal ini menunjukkan bahwa siswa belum baik dalam menulis puisi dari aspek verifikasi (rima dan ritma). 
5. Pada aspek penggunaan majas dan perlambangan berada pada kategori cukup. Hal ini menunjukkan bahwa siswa belum baik dalam menulis puisi dari aspek penggunaan majas dan perlambangan.

Berdasarkan hasil penelitian yang dilakukan dapat dikemukakan saran sebagai berikut:

1. Bagi siswa yang sudah baik dalam menulis puisi diharapkan untuk selalu berlatih dalam kegiatan menulis terutama menulis puisi, sehingga dapat lebih baik dan mampu lagi dalam menulis puisi serta diharapkan dapat membantu teman-teman yang lainnya dalam memahami dan menciptakan sebuah puisi dengan mudah.

2. Bagi siswa yang belum baik dalam menulis puisi diharapkan memiliki buku pegangan yang mencakup materi tentang puisi dan diharapkan siswa lebih sering membaca terutama membaca puisi-puisi yang sudah ada serta lebih banyak berlatih dengan teman-teman yang sudah baik dalam kegiatan menulis puisi sehingga mencapai hasil belajar yang maksimal.

3. Bagi guru, untuk dapat lebih kreatif dalam memberikan suntikan motivasi yang lebih kepada siswa dan guru diharapkan selalu memberikan latihan-latihan guna meningkatkan kemampuan siswa dalam menulis puisi sehingga mencapai hasil belajar yang maksimal serta memberikan pelajaran yang lebih pada siswa yang mendapatkan aspek kategori cukup. Guru juga diharapkan untuk dapat lebih kreatif dalam menggunakan media dan metode pada proses pembelajaran terutama pembelajaran menulis puisi.

\section{DAFTAR PUSTAKA}

Emzir. (2015). Teori dan Pengajaran Sastra. Jakarta: PT RajaGrafindo Persada.

Haliq. A., Asri, A., \& Fitri, S. (2017). Kemampuan Menulis Puisi Mahasiswa Program Studi Pendidikan Bahasa dan Sastra Indonesia dengan Menggunakan Metode Mind Mapping. Proceedings of Nasional Seminar, Research and Community Service Institute, Universitas Negeri Makassar, 144. https://ojs.unm.ac.id/semnaslemlit/article/view/3999

Hasanah, M. (2014). Karakteristik Struktural-Semiotik Puisi-Puisi Karya D. Zawawi imron. LITERA, 12(2). doi:10.21831/ltr.v12i02.1589

Jabrohim, dkk. (2003). Cara Menulis Kreatif. Yogyakarta: Pustaka Pelajar.

Kusumaningsih, D. (2013). Terampil Berbahasa Indonesia. Yogyakarta: CV Andi OFFSET.

Makatita, R., \& Sasabone, C. (2019). Peningkatan Kemampuan Menulis Puisi dengan Menggunakan Teknik Personifikasi Siswa Kelas XI IPS-1 SMA Negeri 8 Ambon. ARBITRER: Jurnal Pendidikan Bahasa dan Sastra Indonesia, 1(1), 29-40. doi:10.30598/arbitrervol1no1hlm29-40

Noermanzah, N. (2012). Figurative Language dalam Wacana Drama Seri "Upin dan Ipin" Karya Simon Monjack dengan Tinjauan Deskriptif. Jurnal Perspektif 
Pendidikan, 5(1), 11-12, $\quad$ https://ojs.stkippgrilubuklinggau.ac.id/index.php/JPP/article/view/347

Noermanzah, N., Abid, S., \& Aprika, E. (2018). Pengaruh Teknik Send a Problem terhadap Kemampuan Menulis Daftar Pustaka Siswa Kelas XI SMA Negeri 4 Lubuklinggau. Jurnal Kajian Bahasa, Sastra dan Pengajaran (KIBASP), 1(2), 171-181. doi:10.31539/kibasp.v1i2.273

Nurgiyantoro, B. (2008). Penilaian dalam Pengajaran Bahasa dan Sastra. Yogyakarta: BPFE Yogyakarta.

Pradopo, R. D. (2014). Pengkajian Puisi. Yogyakarta: DGadjah Mada University Press.

Puspita, H. (2016). Peningkatan Kemampuan Menulis Paragraf Deskriptif Siswa Kelas X SMA Negeri 02 Bengkulu Tengah dengan Menggunakan Metode Menulis Berantai (Estafet Writing). Diksa: Pendidikan Bahasa dan Sastra Indonesia, 2(2), 157-163. doi:10.33369/diksa.v2i2.3456

Rusmiyanti, P. (2018). Peningkatan Kemampuan Menulis Puisi dengan Metode Inkuiri. Dinamika, 1(2), 66. doi:10.35194/jd.v1i2.595

Satinem, S., Juwati, J., \& Noermanzah, N. (2020). Developing Teaching Material of Poetry Appreciation Based on Students Competency Analysis. English Review: Journal of English Education, 8(2), 237. doi:10.25134/erjee.v8i2.2707

Sehah, A. (2016). Pengaruh Model Pembelajaran Kooperatif dan Berpikir Imajinasi terhadap Kemampuan Menulis Puisi. Komposisi: Jurnal Pendidikan Bahasa, Sastra, dan Seni, 17(2). doi:10.24036/komposisi.v17i2.7467

Sutardi, H. K. (2012). Penelitian Sastra Kreatif. Yogyakarta: Graha IImu.

Suwarna, D. (2012). Trik Menulis Puisi, Cerpen, Resensi Buku, Opini/Esai. Bogor: Jelajah Nusa.

Suyitno. (2009). Apresiasi Puisi dan Prosa. Surakarta: UNS Press.

Tarigan, H. G. (2013). Menulis sebagai Suatu Keterampilan Berbahasa. Bandung: CV Angkasa.

Waluyo, H. J. (2008). Pengkajian dan Apresiasi Puisi. Widya Saru Press Salatiga.

Wardoyo, S. M. (2013). Teknik Menulis Puisi. Yogyakarta: Graha IImu.

Zahro, U. A., Noermanzah, \& Syafryadin. (2020). Penguasaan Kosakata Bahasa Indonesia Anak dari Segi Umur, Jenis Kelamin, Jenis Kosakata, Sosial Ekonomi Orang Tua, dan Pekerjaan Orang Tua. Seminar Nasional Pendidikan Bahasa dan Sastra, 1(1), 187-198, https://ejournal.unib.ac.id/index.php/semiba/article/view/13675 